\title{
Histomorphology of chronic gastritis using the Sydney classification system and the Olga staging system at the Laboratory of Anatomic Pathology, Faculty of Medicine, Universitas Sumatera Utara Medan
}

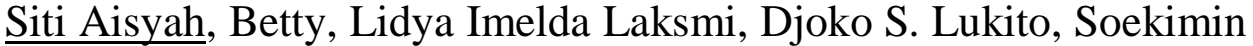 \\ Department of Anatomical Pathology, Faculty of Medicine,Universitas Sumatera Utara, Medan, Indonesia. \\ aisya171215@gmail.com
}

\begin{abstract}
Background: Chronic gastritis is a chronic inflammation of the gastric mucosa and submucosa which is mostly caused by bacteria, mainly associated with $\mathrm{H}$. pylori, causing damage or injury resulting in erosion of the stomach lining with clinical features of dyspepsia. The Sydney classification system is used to diagnose antrum-derived gastritis and corpus biopsy by assessing MN inflammation, PMN inflammation, glandular atrophy, intestinal metaplasia, and the presence of $\mathrm{H}$. pylori bacteria. The Olga staging system is used to assess the degree of atrophy of glands that have a low risk and high risk of developing gastric malignancy.

Objective: To determine the histomorphology of chronic gastritis using the Sydney system classification and the atrophy stage using the Olga system.

Materials and Methods: Histomorphological re-observation was performed on chronic gastritis slides from antrum and corpus biopsy consisting of 114 cases. All characteristic data were obtained through medical record data and pathology archives. The statistical analysis was descriptive with a cross-sectional approach.

Results: There were 114 cases. In the Sydney system classification, the most common histomorphology at antrum and corpus locations are grade 1 of MN inflammation, grade 0 of PMN inflammation, grade 0 of glandular atrophy, grade 0 of metaplasia intestine, and the presence of $\mathrm{H}$. pylori is grade 0 . In the assessment of the atrophy stage according to the Olga system, the most are stage 0 and the least is stage 3 .

Conclusion: The results of this study have various similarities with previous studies, but further investigation and research are needed for better results.
\end{abstract}

Key words: Chronic gastritis, Sydney system, OLGA system, histomorphology

Introduction

Chronic gastritis is a chronic inflammation of the mucosa and submucosa of the stomach of a chronic nature, mostly caused by $\mathrm{H}$. pylori bacteria, drugs, and other irritants, causing damage and erosion of this lining. [1,2] Based on the results of research and observations conducted by the Indonesian Ministry of Health, the incidence of gastritis in several regions in Indonesia is still quite high, with a prevalence of 274.396 cases out of 238.452 .952 people. The highest incidence of gastritis reached $91.6 \%$, namely in the city of Medan, then in several other cities such as Surabaya 31.2\%, Denpasar 46\%, Jakarta 50\%, Bandung 32.5\%, Palembang 35.35\%, Aceh 31.7\%, and Pontianak 31.2\%.[3,4,5,6]

The diagnosis of chronic gastritis must be made based on clinical symptoms, endoscopic examination, and tissue biopsy to assess histological features. [2,7] Assessment of tissue biopsy using the Sydney system classification with a visual analog scale, including assessing the presence or absence of Helicobacter pylori (H. pylori), polymorphonuclear (PMN) and mononuclear (MN) inflammation, glandular atrophy, presence of intestinal metaplasia at an antral or fundal location. [3,8,9] The recommended biopsy protocol is specimens in 2 compartments from antrum and corpus which are submitted separately to the anatomical pathology laboratory.[10,11,12]

International guidelines for carcinoma prevention use the Olga (Operative Link on Gastritis Assessment) staging system to distinguish between low-risk (stage 0 - II) and high-risk (stage III-IV) gastritis for cancer. The Olga system considers the stomach as a lesion indicating disease progression. Assessment of atrophy using the Olga system was carried out by assessing atrophy in the antrum and corpus, then calculating the atrophy score, and then classified it for staging. Atrophy is defined as the loss of glands in the gastric mucosa that can be replaced by connective tissue in the lamina propria. $[3,12,13]$

\section{Materials and methods}

The study was conducted with a cross-sectional approach which included collecting clinical data from medical records, including age, gender, ethnicity, and location of the biopsy (antrum and corpus), followed by a histomorphological examination of gastritis evaluated by three researchers through a microscopic examination on the Hematoxylin \& Eosin staining slides. 
The H\&E stained histopathologic specimens were subjected to a retrospective review by the researchers. Histopathologic slides were examined according to the updated Sydney system standardized visual analogue scale.[14,15,16]

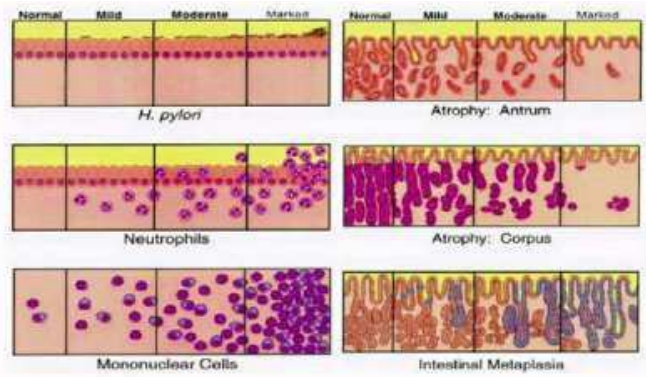

Fig. 1. The updated Sydney system standardized visual analogue scale.[14,15,16]

An assessment of glandular atrophy was obtained by combining the degree of atrophy with the histological score at the site of atrophy. The visual analog scale (VAS) is used as an example of how changes are seen at each level of biopsy sampling. The atrophy score in each biopsy was assessed as the percentage of atrophic glands. Atrophy was assessed on a four-level scale (no atrophy / 0\%, score = 0; mild atrophy / 1-30\%, score $=1$; moderate atrophy / 31-60\%, score $=2$; and severe atrophy, $>60 \%$, score $=3) \cdot[3,12,13]$

Table 1. Olga staging system $[12,13]$

\begin{tabular}{|c|c|c|c|c|c|}
\hline \multicolumn{2}{|c|}{ Atrofi score } & \multicolumn{4}{|c|}{ Corpus } \\
\hline & & Score 0 & Score 1 & Score 2 & Score 3 \\
\hline \multirow{4}{*}{ Antrum } & Score 0 & Stage 0 & Stage I & Stage II & Stage II \\
\hline & Score 1 & Stage I & Stage I & Stage II & Stage III \\
\hline & Score 2 & Stage II & Stage II & Stage III & Stage IV \\
\hline & Score 3 & Stage III & Stage III & Stage IV & Stage IV \\
\hline
\end{tabular}

\section{RESULTS}

In this study, the data obtained came from the archives of the Department of Anatomical Pathology, Faculty of Medicine, Universitas Sumatera Utara, Medan and obtained 210 cases, while those that met the inclusion and exclusion criteria of the antrum and corpus biopsy tissue were 114 cases. The following are the results of the research obtained.

The most inflammation of MN in chronic gastritis according to the classification of the Sydney System is grade $1 \mathrm{MN}$ inflammation, as many as 84 cases $(73.7 \%)$ at the antrum location and as many as 85 cases $(74.6 \%)$ at the corpus location. The least inflammation of $\mathrm{MN}$ was grade 0 , namely 0 cases $(0.0 \%)$ at the antrum location and as many as 3 cases $(2.6 \%)$ at the corpus location. The most PMN inflammation was grade 0 , namely 95 cases $(83.3 \%)$ at the antrum location and 97 cases $(85.1 \%)$ at the corpus location, and the lowest was grade 3 , namely 0 cases $(0.0 \%)$ at the location of the antrum and corpus. For the assessment of glandular atrophy, the most common grade was grade 0, namely 91 cases $(79.8 \%)$ at the antrum location and 102 cases $(89.5 \%)$ at the corpus location, which means that glandular atrophy was not found or there were still many normal. Intestinal metaplasia was not found, meaning that it was at grade 0 , the most was 103 cases $(90.4 \%)$ at the antrum location and as many 106 cases $(93.0 \%)$ at the corpus location, and the least was grade 3, namely as many as 0 cases $(0.0 \%)$ at antrum and corpus location. The most common $\mathrm{H}$. pylori was at grade 0 , namely 111 cases $(97.4 \%)$ at the antrum location and 114 cases (100\%) at the corpus location, and the least number was grade 3, namely 0 cases $(0,0 \%)$ at the location of the antrum and corpus. (Table 2$)$. 
Table 2. Histomorphological distribution according to the Sydney system classification of chronic gastritis.

\begin{tabular}{|c|c|c|c|c|c|}
\hline \multirow{2}{*}{\multicolumn{2}{|c|}{ Histomorphological }} & \multicolumn{2}{|c|}{ Antrum } & \multicolumn{2}{|c|}{ Korpus } \\
\hline & & Amount (n) & Percentage (\%) & Amount (n) & Percentage $(\%)$ \\
\hline \multicolumn{6}{|c|}{ Inflammation of $\mathrm{MN}$} \\
\hline- & 0 & 0 & 0,0 & 3 & 2,6 \\
\hline- & 1 & 84 & 73,7 & 85 & 74,6 \\
\hline- & 2 & 20 & 17,5 & 18 & 15,8 \\
\hline- & 3 & 10 & 8,8 & 8 & 7,0 \\
\hline \multicolumn{6}{|c|}{ Inflammation of PMN } \\
\hline- & 0 & 95 & 83,3 & 97 & 85,1 \\
\hline- & 1 & 14 & 12,3 & 15 & 13,2 \\
\hline- & 2 & 5 & 4,4 & 2 & 1,8 \\
\hline- & 3 & 0 & 0 & 0 & 0 \\
\hline \multicolumn{6}{|c|}{ Glandular atrophy } \\
\hline- & 0 & 91 & 79,8 & 102 & 89,5 \\
\hline- & 1 & 18 & 15,8 & 7 & 6,1 \\
\hline- & 2 & 5 & 4,4 & 5 & 4,4 \\
\hline- & 3 & 0 & 0 & 0 & 0 \\
\hline \multicolumn{6}{|c|}{ Metaplasia intestine } \\
\hline- & 0 & 103 & 90,4 & 106 & 93,0 \\
\hline- & 1 & 10 & 8,8 & 6 & 5,3 \\
\hline- & 2 & 1 & 0,9 & 2 & 1,8 \\
\hline- & 3 & 0 & 0 & 0 & 0 \\
\hline \multicolumn{6}{|c|}{ H. pylori } \\
\hline- & 0 & 111 & 97,4 & 114 & 100,0 \\
\hline- & 1 & 2 & 1,8 & 0 & 0,0 \\
\hline- & 2 & 1 & 0,9 & 0 & 0,0 \\
\hline- & 3 & 0 & 0 & 0 & 0 \\
\hline & & 114 & 100 & 114 & 100 \\
\hline
\end{tabular}

In this study, the mean age was $49.1( \pm 13.7)$ years with the youngest age being 21 years and the oldest being 79 years. Most cases were aged 51-60 years, namely 30 cases $(26.3 \%)$ and the least aged > 71 years were 7 cases $(6.1 \%)$.Most of the sexes were male - 69 people $(60.5 \%)$. The most common ethnic were the Batak, 29 cases (25.4\%) and the least ethnic are Banjar, Nias and Chinese, each with 1 case $(0.9 \%)$.The majority of the types were chemical gastritis / gastropathy as many as 72 cases $(63.2 \%)$ and the lowest was gastritis H. pylori, 2 cases (1.8\%). (Table 3 ).

Table 3. Distribution of samples based on clinicopathological parameters of chronic gastritis.

\begin{tabular}{lcc}
\hline Clinical picture & Amount $(\mathrm{n})$ & Percentage $(\%)$ \\
\hline Age group, mean \pm SD years & $49,1 \pm 13,7$ & 9,7 \\
$20-30$ years & 11 & 17,6 \\
$31-40$ years & 20 & 25,4 \\
$41-50$ years & 29 & 26,3 \\
$51-60$ years & 30 & 14,9 \\
$61-70$ years & 17 & 6,1 \\
$71-80$ years & 7 & 60,5 \\
Gender & & 6 \\
Male & 69 & \\
\hline
\end{tabular}




$\begin{array}{lcc}\text { Female } & 45 & 39,5 \\ \text { Ethnic } & 2 & 1,8 \\ \text { Karo } & 25 & 21,9 \\ \text { Mandailing } & 10 & 8,8 \\ \text { Melayu } & 1 & 0,9 \\ \text { India } & 22 & 19,3 \\ \text { Jawa } & 29 & 25,4 \\ \text { Batak } & 1 & 0,9 \\ \text { Banjar } & 9 & 7,9 \\ \text { Minang } & 4 & 3,5 \\ \text { Simalungun } & 6 & 5,3 \\ \text { Aceh } & 1 & 0,9 \\ \text { Nias } & 3 & 2,6 \\ \text { Palembang } & 1 & 0,9 \\ \text { Cina } & & \\ \text { Diagnose } & 72 & 63,2 \\ \text { Chemical gastritis/gastropathy } & 23 & 20,2 \\ \text { Atrophic gastritis } & 7 & 6,1 \\ \text { Active chronic gastritis } & 2 & 1,8 \\ \text { H. pylori gastritis } & 2 & 1,8 \\ \text { Eosinophilic gastritis } & 8 & 7,0 \\ \text { Lymphocytic gastritis } & & \end{array}$
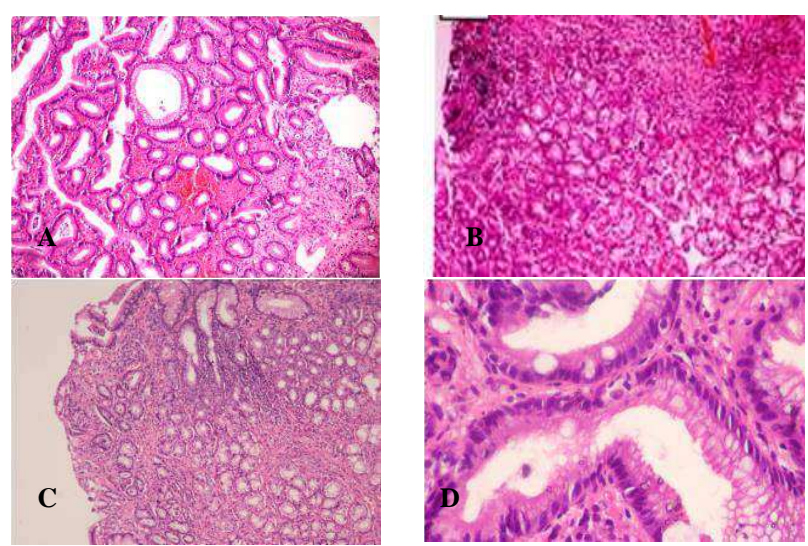

Fig 2. A. Infiltration of grade $1 \mathrm{MN}$ inflammatory cells (H\&E 100x) B. Infiltration of PMN inflammation (H\&E 40x) C. Glandular atrophy (H\&E 40x) D. Intestinal metaplasia (H\&E 100x)

Assessment of atrophy staging according to the OLGA system, the most was staging 0 or no atrophy, as many as 89 cases $(78.1 \%)$ and the least was staging 3 as many as 3 cases $(2.6 \%)$, followed by staging 2 as many as 4 cases ( $3.5 \%)$ and staging 1 in 18 cases (15.8\%) (Table 4).

Table 4. Distribution of atrophic staging according to the Olga system in chronic gastritis.

\begin{tabular}{lrcc}
\hline \multicolumn{2}{c}{ Staging Olga } & Amount (n) & Percentage (\%) \\
\hline & Staging 0 & 89 & 78,1 \\
- & Staging 1 & 18 & 15,8 \\
- & Staging 2 & 4 & 3,5 \\
- & Staging 3 & 3 & 2,6 \\
- & Staging 4 & 0 & 0 \\
\hline
\end{tabular}



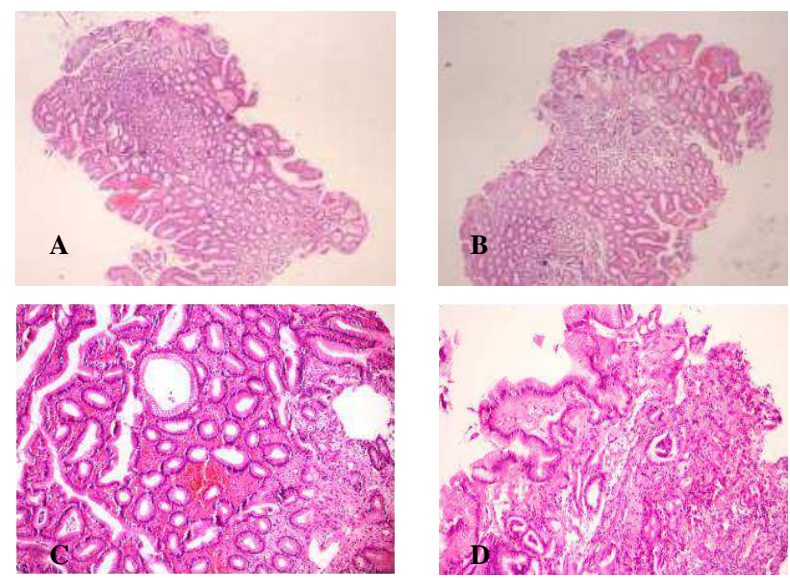

Fig 3. A\&B. There was no atrophy at the site of the antrum and corpus (H\&E 40x). C. Mild glandular atrophy (H\&E 100x) D. Moderate glandular atrophy $(\mathrm{H} \& \mathrm{E} 100 \mathrm{x})$

\section{DISCUSSION}

Based on this study, it was found that there were more men than women (Table 3). This is in accordance with the study by Ariefanny et al, which showed that chronic gastritis was more common in men, as many as $66.7 \%$ of cases.[17] Tammasse IFU et al also found the same result that there are more men than women.[18] Nurdin et al also stated the same result with a male percentage of 50.6\%.[3] However, the results of this study are different from the results of a study conducted by Hussein et al which found more female than male gender.[10] The differences in the results of this study may occur due to differences in eating habits or diets between male and female. In adulthood, there are differences in diet between male and female, this is due to differences in activity and body composition. Selection of food, women tend to avoid large portions and reduce the frequency of eating. Also related to the level of stress. In psychological theory, it is stated that female use feelings and emotions more so they are prone to experiencing psychological stress or anxiety in their lives.[19.20]

The age grouping of chronic ulcer patients is divided into six groups. In this study, it was found that the most chronic gastritis cases were aged 51-60 years with a percentage of $26.3 \%$. This is in line with Nurdin et al's research, which mostly was at the age of 51-60 years, namely 36 cases (21.7\%).[3] Hussein et al also obtained results that were not much different, most were> 60 years old.[10] In Ariefiany et al's study, it was not much different where the most age was 61-70 years.[17] Correspondingly, Garg et al. Also stated that the highest proportion was at the age of 46-60 years.[21] This is consistent with the theory that chronic gastritis is more common in adults than in children.[19]

Based on ethnicity, the Batak ethnic group is the most common with a percentage of $25.4 \%$. This research was conducted in the city of Medan where the most ethnic groups in this city are the Batak people. Cultural and ethnic factors are very influential in eating habits, for example the amount of food eaten, the habit of eating spicy and sour foods. [19,20,22]

Chemical gastritis / gastropathy, one of the most common types of chronic gastritis in this study, was $63.2 \%$. It is based on an analysis of data from the Sydney classification system. There is still not much research on this. Histopathological features according to the Sydney system classification, the degree of inflammation of MN that was most often found in the antrum and corpus was gradation 1 with a proportion of $73.7 \%$ and $74.6 \%$. Similar to the study of Nurdin et al in 116 cases of chronic gastritis, stated that the highest degree of inflammation was grade 1 at the antrum and corpus location with a proportion of $69.3 \%$ and $83.1 \%$. [3] Daniel and Mario's study had a different incidence of degree of inflammation, namely grade 2 in $46 \%$ of 200 cases. [23] Abdel et al stated that the highest degree of inflammation was 0 with a total of 170 cases out of 328 cases in the corpus area and 128 cases in the antrum area. [24] The difference in the results of this study has many factors, one of which is due to the long history of gastritis in the patient before the biopsy. This is consistent with the theory that gastritis is associated with a lot of inflammation of MN. [17]

Based on PMN activities, the most common ones were grade 0 in the antrum and corpus with a percentage of $83.3 \%$ and $85.1 \%$ of 114 cases. It is the same with Daniel and Mario's research which stated that grade 0 was the most with a percentage of $83.5 \%$ of 200 cases. [23] Husssein et al, said different results, where the most PMN inflammation was grade 2 with a percentage of $41.7 \%$ of cases from 100 
samples that only came from the antrum. [10] According to Ariefiany, the most common result was grade 2. [17]

Assessment of glandular atrophy, the most grade was grade 0 or normal with a percentage of $79.8 \%$ in the antrum area and $89.5 \%$ in the corpus area. Similar to the study of Nurdin et al, that the grade of atrophy is grading 0 with a percentage of $47 \%$ in the antrum area and $74.1 \%$ in the corpus area of 166 cases. Ariefiany also stated that the most atrophic grading was 0 with a percentage of $64.3 \%$ in the antrum and corpus areas. Same with Daniel and Mario, who stated that grade 0 or normal was the highest grade with a percentage of $100 \%$ of the 200 samples. In accordance with the theory which states that glandular atrophy often occurs in atrophic gatritis, while in this study the dominant type of gastritis was chemical gastritis / gastrophaty.

The most common grade of intestinal metaplasia was 0 or normal, with a percentage of $90.4 \%$ of cases in the antrum area and $93.0 \%$ in the corpus area. Similar to the research of Nurdin et al., The most common grade is 0 or normal with a percentage of $90.4 \%$ in the antrum area and $97 \%$ in the corpus area. [3] Ariefiany et al stated that the highest grade is 0 or normal. [17] Husein et al also obtained the same results, with the highest grade being grade 0. [10] Abdil et al who stated that the highest grade was 0 with 321 cases in the corpus area and 315 cases in the antrum area out of 328 cases. [24] In this study there were still many normal glands found in most samples and also because there was no special staining. for mucin can increase the diagnostic rate of instestinal metaplastic. Determination of the biospi region, namely incisura angularis, also has an added value in detecting intestinal metaplasia. [17,24]

The highest grade $\mathrm{H}$. pylori was grade 0 with a percentage of $97.4 \%$ in the antrum area and $100 \%$ in the corpus area. Similar to the study by Nurdin et al, that H. pylori was not found in 162 cases out of 166 cases. [3] Ariefiany et al stated that H. pylori was not found in 20 of 42 cases with a percentage of 47.6\%. [10] Similar to Daniel and Mario, H. pylori was not found in 173 cases out of 200 cases. These results were obtained because H. pylori is difficult to see by H\&E staining if the amount is small which is a weakness of this study, or because the patient has undergone treatment so that the bacterial infection is reduced or no longer visible due to the drug that has been given. $[17,23]$

Atrophy stage assessment using the Olga system in this study the most commonly found was stage 0 or normal with a percentage of $78.1 \%$. Similar to the research results, Nurdin et al stated that the highest proportion was stage 0 with a percentage of $90.4 \%$ of cases. [3] Naimovna et al, stated that the most stage 0 in the corpus and stage 2 in the antrum with a percentage of cases 55\% and 38.3\%. [25]

\section{Conclusion}

In this study, there were 114 cases of chronic gastritis, consisting of 69 cases of men and 45 cases of women. The most age range was 51-60 years and the lowest was > 70 years. The tribe that is mostly found in the Batak tribe is 29 cases. In the Sydney system classification, the most common histomorphologies at the antrum and corpus sites are grade 1 for MN inflammation, grade 0 for PMN activity, grade 0 for gland atrophy, grade 0 for intestinal metaplasia, and grade $0 \mathrm{H}$. pylori. Atrophy assessment is performed to assess the risk of gastric cancer in chronic gastritis. Although the Olga system aims to categorize cancer risk and has been used for more than 10 years, there is still little research on the use of the Olga system in the history of gastric cancer.

\section{COMPETING INTERESTS}

The author has no financial interests that are relevant to the products or company described in this article.

\section{ACKNOWLEDGEMENT}

We acknowledge to all staff and resident of Anatomical Pathology Department of North Sumatra University, H.AdamMalik hospital, Medan, Indonesia for all its help and cooperation.

\section{ETHICAL APROVAL}

The Health Research Ethical Committee, Universitas Sumatera Utara, Medan, Indonesia approved this study. 


\section{REFERENCES}

1. Hirian. 2014. Gastritis kronik. In Issel bacher KJ. Harrison Prinsip - Prinsip Ilmu Penyakit Dalam Edisi 13, Jakarta. EGC. pp509-22

2. Sudoyo AW, Setiyohadi B, Alwi, Simadibrata M, Setiati S. 2014. Gastritis Indonesia, Jakarta: Pusat Penerbitan Ilmu Penyakit Dalam FKUI. pp523-27

3. Nurdin W, Krisnuhoni E. 2016. Perbandingan assessment gastritis kronis berdasarkan updated Sydney system dan OLGA, OLGYM System di Departemen Patologi Anatomik FKUI/RSCM Tahun 2012. Majalah Patologi. Vol.5. pp74-81

4. Badan Penelitian dan Pengembangan Kesehatan. 2013. Riset Kesehatan Dasar (RISKESDAS) 2013. Laporan Nasional 2013. pp1-384.

5. Ariefiany D, Hassan AH, Dewayani BM, Yantisetiasti A. 2014. Analisis Gambaran Histopatologi Gastritis Kronis dengan dan Tanpa Majalah Patologi. Vol. 23 No. 2. pp1-6

6. Sunarmi. 2018. Faktor-faktor yang berisiko dengan kejadian penyakit gastritis di poliklinik penyakit dalam rumah sakit muhammadiyah palembang tahun 2018. Volume 8. pp.1-5

7. Kumar V, Abbas AK, Fausto N, Aster JC. 2018. Oral Cavity and Gastrointestinal tract. Robbins Basic Pathology. 10th ed. Philladelpia; Elsevier Saunders. pp603-598

8. Nisa F. 2018. Gastritis (Warm-e-meda): A review with Unani approach. International Journal of Advanced Science and Research. Volume 3. pp43-45

9. Feneglio PCM, Noffsinger AF, Stemmermann GN, Lantz PE, Isaacson PG. 2008. Chapter 4: The nonneoplastic stomach. In : Noffsinger AF, Stemmermann GN, Lantz PE, Isaacson PG. Gastrointestinal Pathology: An Atlas and Text, 3rd Edition. Lippincott Williams \& Wilkins. pp18286

10. Hussein A H. 2019. Evaluation of chronic gastritis in endoscopic antral biopsies using the updated Sydney system. Ann coll med mosul. pp95-05

11. Pruthi S, Nirupama M, Chakraborti S. 2014. Evaluation of gastric biopsies in chronic gastritis: Grading of inflammation by Visual Analogue Scale Department of Pathology. Vol. 7(4). pp463-67

12. Ruggea M, Pennelli G, Pilozzi E, Fassan M, Ingravallo G, Russoe VM, et al. 2011. Gastritis: The histology report. pp373-84

13. Ruggae M. 2019.Gastritis and metaplasia: precursors of gastric neoplasms. In: WHO Classification of Digestive System Tumours,5th ed; Vol 1.Lyon (France). IARC. pp66-65

14. Carrasco G \& Corvalan AH. 2013. Review Article H. pylori-Induced Chronic Gastritis and Assessing Risks for Gastric Cancer Hindawi Publishing Corporation Gastroenterology Research and Practice. pp1-8

15. Hassan TM, Al-Najjar S, Al-Zahrani I, Alanazi F, Alotibi MG. 2016. Helicobacter pylori chronic gastritis updated Sydney grading in relation to endoscopic findings and H. pylori IgG antibody diagnostic methods. Journal of Microscopy and Ultrastructure.pp167-74

16. Tasci ES, Akbas T. 2019. The Relationship between the Sydney Classification and the First-Line Treatment Efficacy in Helicobacter-Associated Gastritis. Med Princ Pract. pp1-7

17. Ariefiany D, Hassan AH, Dewayani BM, Yantisetiasti A. 2014. Analisis Gambaran Histopatologi Gastritis Kronis dengan dan Tanpa Majalah Patologi. Vol. 23 No. 2. pp1-6

18. Tammase UFI dan Miskad US. 2017. Analisis gambaran histopatologi mukosa lambung dan bakteri helicobacter pylori pada pasien gastritis di rsup dr. wahidin sudirohusodo tahun 2016. Program studi pendidikan dokter Fakultas Kedokteran Universitas Hasanuddin Makassar. pp82-96

19. Pasaribu MP, Lampus BS, Sapulete M. 2014. The relationship between eating habits with the gastritis at the medical faculty level of student 2010 Sam Ratulangi University Manado. Jurnal kedokteran komunitas dan tropik: volume 2 nomor 2. pp49-57

20. Hartati $\mathrm{S}$ dan Cahyaningsih E. 2015. Hubungan perilaku makan dengan kejadian gastritis pada mahasiswa akper manggala husada Jakarta tahun 2013. Jurnal keperawatan. volume 6 nomor 1. pp51-56

21. Garg B, Sandhu V, Sood N, Sood A, Malhotra V. 2012. histopathological analysis of chronic gastritis and correlation of pathological features with each other and with endoscopic findings. Pol $\mathrm{j}$ pathol(3). pp172-78

22. Handayani SD, Kosasih CE, Priambodo AP. 2015. Hubungan dukungan keluarga dengan kekambuhan pasien gastritis di Pueskesmas Jatinangor. Fakultas Ilmu Keperawatan Universitas Padjajaran, Bandung. pp1-15 
23. Daniel M dan Mario S. 2017. Histopatological Profile in Patient with Chronic Gastritis Who Underwent EGD in Wangaya Hospital Using Sydney System. International Journal of Science and Research (IJSR). Volume 1 Issue 11. pp1902-07

24. Abdel LM, Batin H, Shahin R, Shwaqy A, Arafa M, Gafar S, et al. 2016. Value of Additional Corpus Biopsy for Diagnosis of Helicobacter Pylori in Atrophic Gastritis. Clinics in Surgery. pp1-6

25. Naimovna SG, Kurbanovna A, Shukurleovna NM, Jabborovna AI. 2020. Evaluation of the gastrointestinal mucosa by the OLGA system in chronic atrophic gastritis. Journal of Critical Reviews. Vol 7 Issues 2. pp409-13

\section{AUTHORS DETAILS}

First Author - dr. Siti Aisyah, resident of Anatomical Pathology Departement, Faculty of Medicine, Universitas Sumatera Utara, Medan, Indonesia, id email: aisya171215@gmail.com

Second Author - Dr. dr. Betty, M.ked(PA), Sp.PA (K), Lectures and Staff Anatomical Pathology Department, Faculty of Medicine, Universitas Sumatera Utara, Medan, Indonesia

Third Author - Dr. dr. Lidya Imelda Laksmi, M.Ked (PA), Sp. PA, Lectures and staff Anatomical Pathology Department, Faculty of Medicine, Universitas Sumatera Utara, Medan, Indonesia.

Fourth Author - dr. Djoko S. Lukito, Sp.PA (K), Lectures and Staff Anatomical Pathology Department, Faculty of Medicine, Universitas Sumatera Utara, Medan, Indonesia

Fifth Author - dr. H. Soekimin, Sp.PA (K), Lectures and Staff Anatomical Pathology Department, Faculty of Medicine, Universitas Sumatera Utara, Medan, Indonesia

Corresponding Author - Siti Aisyah, resident of Anatomical Pathology Department, Faculty of Medicine,University of North Sumatra, Jl. Universitas. No. 1 gedung Abdul Hakim, Medan, Indonesia, Email ID: aisya171215@gmail.com 